\title{
If-conditional sentences across Asian Englishes
}

\author{
Ariel Robert C. Ponce, MA
}

ponce.arc@ndu.edu.ph

Notre Dame University, The Philippines

\author{
Shirley N. Dita, PhD \\ shirley.dita@dlsu.edu.ph
}

De La Salle University-Manila, The Philippines

\begin{abstract}
This study explored the syntactic and semantic analysis of if-conditional sentences in the International Corpus of English (ICE). Using the three corpora of Asian varieties of English such as ICE-PHI (PhilE), ICE-HK (HKE), and ICE-SING (SingE) that have 6,375 ifconditional sentences in total, structural analysis of the corpus revealed that the simple present verb in both conditional and main clauses was the most frequent verb combination in spoken and written PhilE and SingE while simple present and modal + verb were found to be the most widely used in HKE. Moreover, PhilE had the most number of open conditionals and the least attestation of hypothetical conditionals in written and spoken data. Conversely, in all the genres of the corpus, HKE conveyed much more hypothetical conditionals than open conditionals. These data indicate that the verb combinations and semantic categories of conditional sentences used in these Asian countries may vary; hence, a shift in pedagogical orientation and classroom practices should be contextualized for different groups of English language learners. Further, directions for future research were provided.
\end{abstract}

Keywords: if-conditional, conditional, corpus linguistics 


\section{Introduction}

In the advent of Communicative Language Teaching (CLT) influenced by the constructivist approach that proposes that "meaningful learning develop through authentic tasks" (Good \& Brophy, 1994, p. 142 as cited in Cooperstein \& Kocevar-Weidinger, 2004), various strategies came to replace the overt method of teaching grammar. This approach enables learners to engage in activities through which they develop skills and acquire concepts. Although language teaching nowadays can be done in various ways, English conditional sentences (e.g. I would buy that phone if I had enough money), for example, have been taught in most schools, particularly in ESL and EFL contexts, in a manner where the concept is presented first and activities are given later. It is still undeniable that grammatical rules and structures are explicitly taught among learners through course books, textbooks, and worksheets among others.

According to Celce-Murcia and Lancer-Freeman (1999), most ESL/EFL grammar references or textbooks provide highly oversimplified information about conditional sentences. These materials would prescribe rules and/or typologies in writing English conditional sentences. The traditional typology suggested by Leech (2011) is classified into three. These are the first condition formed by if + present simple in the conditional clause and will + base of the verb in the main clause (e.g. If the rain stops, I will join the picnic), second condition formed by using the simple past tense of the verb in the if-clause and would + base form of the verb in the main clause (e.g. If I bought the dress, I would be happy right now), and third conditional sentence that uses past perfective aspect in the conditional clause and modal would + perfective aspect in the main clause (e.g. If I had studied my lesson, I would have passed the examination). However, Gabrielatos $(2003 ; 2006)$ argued that such a typology adopts a naïve and restricted approach to modal marking in conditional sentences, as this tends to focus only on central modals (i.e. can, could, may, might, must, shall, should, will, would).

As early as 1960, adverbial subordinate clauses, specifically if-conditionals, have been investigated. Hill (1960) found that there were at least 324 finite verb combinations that would occur in both main clause and if-clause (e.g. "If you go, he'll be going soon after" [p.166] and "If she's washing up the dishes, they've obviously finished breakfast" [p.167]). Up to the present, there are still explorations in this particular grammatical aspect of English (e.g. Elder \& Jaszczolt, 2016; Hasselgård, 2016) because of the complexity of its structure and semantic value. Gabrielatos 
(2013) noted that presentations of if-conditional sentences in English materials such as course books are not only incomplete but also distorted.

With the foregoing assertion of highly simplistic presentations of these conditionals in pedagogical materials, where limited verb forms are presented in the conditional and main clauses, it is worth investigating what verb combinations and semantic categories are present in corpora, which are composed of naturally occurring utterances and statements in different domains, that most reference materials fail to present.

\section{Literature Review}

\subsection{Corpus-based studies on conditional sentences}

Using the Brown Corpus and Lancaster-Oslo-Bergen (LOB) Corpus, Wang (1991 as cited in Kennedy, 1998) explored the verb combinations of 4,324 tokens of if-conditional sentences of these corpora. She found 76 possible combinations in Brown and 103 in the LOB. The top two common verb combinations found were simple present for both if-clause and main clause and simple present in if-clause and will/shall/be going to + base form of the verb for the main clause, respectively. Moreover, she found that open conditionals were much frequent in both corpora (e.g. If you heat air, it rises and I get a headache if I eat too many nuts).

Meanwhile, Gabrielatos (2010) examined English if-conditional sentences through the lens of modality. His dissertation studied the relation of conditionals to modality using the written British National Corpus (BNC). He concluded that types of conditionals and modal load patterns were found to have a correlation in their respective protases (subordinate clause) and apodoses (main clause). In a later study, he surveyed if-conditionals in The International Corpus of Learner English (ICLE) and the BNC. He used two random samples of if-conditional sentences demonstrating learner and L1 use in written discourse from a corpus of student writing at upperintermediate and advanced levels. The findings of the study revealed that the use of if-conditionals found in the ICLE is not strongly influenced by the shortcomings of the ELT typology and related pedagogical information (i.e. limited verb phrase structures presented in the course materials) (Gabrielatos, 2013).

Hasselgård (2016) investigated the syntactic, semantic, and pragmatic features of conditional clauses in novice academic English. For this investigation, she used the Varieties of 
English for Specific Purposes dAtabase (VESPA) which consists of the Norwegian advanced learners of English and the British Academic Written English Corpus (BAWE) and representative of English L1 students in British universities. The results revealed that, generally, there was an overuse of conditional sentences among learners which can be accounted for the pragmatic function of conditional sentences (i.e. asking questions) for example, "If the main argument of the book is to be mindful of the slippery slope, why does the post-pandemic scenario seem preferable to the pre-pandemic scenario? (VESPA)" (p.109).

Another corpus-based investigation of if-conditionals is reported by Elder and Jaszczolt (2016). They approached if-conditional sentences using a pragmatic lens rather than approaching them syntactically. They recommended a pragmatic category with supporting theoretical arguments and example sentences from the British component of the International Corpus of English (ICE-GB).

\subsection{Other studies on conditional sentences}

English conditional sentences have been identified as a difficult area of English to acquire (Gabrielatos, 2013). With this, a number of explorations were conducted specifically pertaining to verb tense and modals. Conditional sentences technically are not simple to acquire for students even though it is the most common conditional marker. This may be due to the different verb phrase combinations for a corresponding type of conditional and its semantics as prescribed by textbooks. For instance, Type 2 conditionals, found in print materials, are expressed using simple past in the conditional clause and would + infinitive in the main clause (e.g. If I found her address, I would send her an invitation).

Bloom et al. (1980) examined the acquisition of the if-conditional among learners and found that learners had slow processing in the acquisition of such grammatical construction. In fact, Covitt (1976 in Al Rdaat, 2017) argued that "The significant issues pertaining to conditional sentences involve four angles: forms, meanings, time-tense linkages, and simplified interpretations."

On the other hand, Al Rdaat (2017) analyzed students' use of English conditional sentences in both semantic and syntactic situations. Twenty Arab students who were students of different levels (bachelor, master, and Ph.D.) answered a questionnaire. The results of the study found that 
most of the student-respondents found it difficult to comprehend and utilize conditional sentences, particularly the Type 3 conditional (e.g. If they had worked more, their job would have been developed).

Interestingly, conditional sentences were also explored in other languages. Mejias-Bikandi (2009) examined the use of mood in conditional subordinate clauses in Spanish. He found that si (if) is not subordinating conjunction that grammatically institutes a relational meaning between two clauses, but si (if) is a particle that orders the hearer to establish a suppositional view where two schemes hold as in: "Si conoces [al que te robo' la cartera]i, denu' ncialei. (If you know [the one who stole your wallet], sue him) (p.166).

With the foregoing arguments and studies on subordinate clauses in general and ifconditional sentences in particular, conditionals are an important area of research in several respects. Their use in hypothesizing and the expression of possible worlds have made them one of the central concerns, and areas of difficulty in propositional logic (Gabrielatos, 2010).

\subsection{Research Gap}

As seen in the preceding paragraphs, although there were already investigations about ifconditional sentences, there are only a few that utilized corpora, which are accessible database of naturally occurring utterances. Also, previous studies barely explored the International Corpus of English (ICE) and that the eastern part of the globe particularly the Asian countries were left out in the empirical discourse, thus, making this area of inquiry still limited. As a result, only the simplistic structures of conditional sentences are included in textbooks and other reference books used in classroom teaching.

Therefore, this paper addresses the gap by analyzing if-conditional sentences in three Asian English corpora such as ICE-Philippines, ICE-Hong Kong, and ICE-Singapore. The results of this study may add to the scarce documentation of English conditional sentences particularly the verb combinations and semantic categories in the Asian English corpora. Also, the findings are hoped to inform pedagogical practices in the teaching of conditional sentences across Asia. 


\subsection{Research Questions}

This paper described the if-conditional sentences in three Asian corpora of ICE by analyzing its structural and semantical categories. Specifically, it answered the following questions:

1. What are the verb forms in if-clause and main clause in PhilE, HKE, and SingE in spoken and written corpora?

2. What are the verb combinations in if-conditional sentences in PhilE, HKE, and SingE spoken and written corpora?

3. What are the semantic categories of if-conditional sentences in PhilE, HKE, and SingE spoken and written corpora?

\section{Theoretical Framework}

This research was anchored on Quirk et al.'s (1985) notion of the if-conditional sentence. According to Quirk et al. (1985), a conditional sentence is a subordinate clause that may express a direct condition. This means that conditional sentences communicate a situation in the matrix clause (or apodosis) that is directly contingent on that of the conditional clause (protasis).

Moreover, a direct condition may either be an open condition or a hypothetical condition. Open conditions are neutral in that they leave unresolved the question of the accomplishment or non-accomplishment of a certain condition, and also the truth value of the proposition expressed by the matrix clause. For example,

(1) But if you want to get a better degree you have to work hard really. (ICE-HK:S1A-042)

(2) I'll be damned if I'm going to find out! (ICE-HKW2F-017)

A hypothetical condition, on the other hand, refers to the speaker's belief that the condition will not be fulfilled (for future conditions), is not fulfilled (for present conditions), or was not fulfilled (for past conditions), and hence the probable or certain falsity of the proposition expressed by the matrix clause. The following sentences are classified as hypothetical conditional sentences:

(3) He could have been a sociologist if he had wanted to be one. (ICE-HKW2F-013)

(4) If I had my own choice, I would have refused the offer (ICE-HKW2F-002) 


\section{Methodology}

The data of this study came from the International Corpus of English (ICE) particularly the Philippine component (ICE-PHI), Hong Kong component (ICE-HK), and Singaporean component (ICE-SING). Table 1 presents the distribution of the following corpora.

Table 1. Word count of the surveyed ICE components

\begin{tabular}{cccc}
\hline ICE Component & Spoken & Written & Total \\
\hline Philippines (PhilE) & 687,239 & 452,196 & $1,139,435$ \\
Hong Kong (HKE) & 975,063 & 498,893 & $1,473,956$ \\
Singapore (SingE) & 681,879 & 436,307 & $1,118,186$ \\
Total & $2,344,181$ & $1,387,396$ & $3,731,577$ \\
\hline
\end{tabular}

All the corpora were processed using AntConc (v 3.5.6). Manual weeding of utterances and sentences were done for the analysis of if-conditional sentences. Those that used subordinators such as if (5) and even if (6) were excluded from the analysis because these subordinators may not always indicate a cause-effect relationship (Gauker, 2005).

(5) ...you would feel like as if a dust particle has entered your eye <indig > para ka lang napuwing </indig $>\quad<$ ICE-PHI:S1B-074>

(6) Even if he only wants to alter the front <ICE-SING:W2A-010>

Moreover, conditional sentences that are indirect in nature (7) (i.e. those that function as adjuncts or insubordinate if-conditions), occurrences that have elliptical constructions (8) and ifclauses that function as noun clauses (9) were also excluded from the sample. From there, verb combinations were identified for the if-clause and matrix clause.

(7) Uh perhaps if I may have the benefit of having the costs $<\mathrm{ICE}-\mathrm{HK}: \mathrm{S} 1 \mathrm{~B}-061>$

(8) if allowed by the COMELEC if allowed by the Armed Forces and if supported by the President <ICE-PHI:S1B-021>

(9) I wonder if this is worth anything <ICE-SING:W2F-008>

In addition, the sentences were semantically analyzed as open conditional (10) that do not convey the certainty or uncertainty of the fulfillment of expression, or hypothetical conditional (11) that express the impossibility of the realization of the statement in the main clause.

(10) If Asia collapses, the entire world has to collapse. <ICE-PHI:W2B-011> 
(11) if blame is to be laid on anyone's shoulder I would say that it should be placed on those who had run of the military establishment for so long but had not been able $<$ ICE-PHI:S2B035>

\section{Results}

The analysis of three Asian English varieties generated 2,258 conditional sentences from ICE-PHI (PhilE), 1,024 from ICE-HK (HKE), and 3,093 from ICE-SING (SingE), yielding 6,375 ifconditional sentences combined.

\subsection{Verb form in if-clause and main clause (Spoken)}

Across the sampling of the three spoken Asian corpora, Table 2 reveals that the simple present tense appears to be the most frequently used type of verb (form?) in the if-clause Singaporean English (SingE, 12), Hong Kong English (HKE, 13), and Philippine English (PhilE, 14) where it gained more attestations in comparison with other verb forms.

(12) if it makes sense to you uh after due delineation have been exercised push on with it $<\mathrm{X}><$ ICE-SIN:S1B-034>

(13) if you uh reject or don't buy anything <ICE-HK:S1A-021>

(14) if all hostages are released <ICE-PHI:S2B-006>

Moreover, simple past form of the verb is also used in the protasis, the clause expressing condition in a conditional sentence. PhilE was found to use simple past more frequently compared with the other two English varieties as in:

(15) If a man 's foot measured thirty-nine barley corns that was considered the equivalent of thirteen inches in shoes <ICE-PHI:S2B-017 >

However, modal + verb combination was evident in if-conditional sentences of SingE (16) and $\operatorname{HKE}$ (17), respectively.

(16) If Mr Heng can let me know the type of houses he has in mind in his constituency which are in such a bad state <ICE-SINGS1B-054>

(17) If we can decide today and <,> inform them about our decision <, > tomorrow <ICEHK:S1A-016> 
Table 2. Comparison of verb forms in if-clause of three Corpora (Spoken)

\begin{tabular}{lcccccc}
\hline \multicolumn{1}{c}{ Verb form } & \multicolumn{2}{c}{ PH } & \multicolumn{2}{c}{ HK } & \multicolumn{2}{c}{ SING } \\
& F & $\%$ & F & $\%$ & F & $\%$ \\
\hline Simple Present & 1236 & 70.99 & 370 & 71.57 & 1554 & 75.00 \\
Simple Past & 188 & 10.80 & 53 & 10.25 & 166 & 8.01 \\
will + base & 84 & 4.82 & 2 & 0.39 & 13 & 0.63 \\
present perfect & 113 & 6.49 & 13 & 2.51 & 33 & 1.59 \\
will + present perfect & 0 & 0 & 0 & 0 & 1 & 0.05 \\
Past perfect & 18 & 1.03 & 10 & 1.93 & 12 & 0.58 \\
would + present perfect & 6 & 0.34 & 0 & 0.00 & 0 & 0.00 \\
present progressive & 6 & 0.34 & 0 & 0 & 1 & 0.05 \\
past progressive & 0 & 0 & 17 & 3.29 & 3 & 0.14 \\
present perfect progressive & 2 & 0.11 & 0 & 0 & 0 & 0.00 \\
past perfect progressive & 3 & 0.17 & 0 & 0 & 0 & 0.00 \\
modal + verb & 85 & 4.88 & 52 & 10.06 & 289 & 13.95 \\
Total & 1741 & 100.00 & 517 & 100.00 & 2072 & 100.00 \\
\hline
\end{tabular}

With regard to the verb used in the main clause of spoken corpora of three varieties of Englishes, more than half of the clause used the simple present tense in (18) PhilE (57.55\%) and (19) SingE (54.30\%). Interestingly, (20) HKE corpus generated main clauses that used modal + verb $(39.65 \%)$.

(18) We catch smugglers to protect our local manufacturers who are being prejudiced by the items... $<$ ICE-PHIS2A-039>

(19) this whole lot on the right hand side is assumed to be known okay so in that case how to get hold of my unknowns... $<\mathrm{ICE}-\mathrm{SIN}$ :S1B-003>

(20) we may we may hesitate... <ICE-HK:S1A-070> 
Table 3. Comparison of verb forms in the main clause of three Corpora (Spoken)

\begin{tabular}{lcccccc}
\hline \multicolumn{1}{c}{ Verb form } & \multicolumn{2}{c}{ PH } & \multicolumn{2}{c}{ HK } & \multicolumn{3}{c}{ SING } \\
& F & $\%$ & F & $\%$ & F & $\%$ \\
\hline Simple Present & 1002 & 57.55 & 116 & 22.44 & 1125 & 54.30 \\
Simple Past & 137 & 7.87 & 7 & 1.35 & 69 & 3.33 \\
will + base & 187 & 10.74 & 160 & 30.95 & 272 & 13.13 \\
present perfect & 105 & 6.03 & 2 & 0.39 & 38 & 1.83 \\
will + present perfect & 9 & 0.52 & 1 & 0.19 & 0 & 0.00 \\
Past perfect & 13 & 0.75 & 1 & 0.19 & 5 & 0.24 \\
could + present perfect & 0 & 0.00 & 4 & 0.77 & 0 & 0.00 \\
might + present perfect & 0 & 0.00 & 3 & 0.58 & 0 & 0.00 \\
would + present perfect & 13 & 0.75 & 12 & 2.32 & 24 & 1.16 \\
present progressive & 3 & 0.17 & 6 & 1.16 & 2 & 0.10 \\
past progressive & 0 & 0.00 & 0 & 0.00 & 0 & 0.00 \\
present perfect progressive & 7 & 0.40 & 0 & 0.00 & 0 & 0.00 \\
past perfect progressive & 1 & 0.06 & 0 & 0.00 & 0 & 0.00 \\
modal + base & 264 & 15.16 & 205 & 39.65 & 537 & 25.92 \\
Total & 1741 & 100.00 & 517 & 100.00 & 2072 & 100.00 \\
\hline
\end{tabular}

\subsection{Verb form in if-clause and main clause (Written)}

For the written corpora of PhilE, HKE, and SingE, Table 4 presents the verb form used in if-clause across these three varieties.

Like the spoken counterpart, the simple present remains to be the verb that is frequently used in the if-clause. HKE (69.43\%) used simple present as much as PhilE (68.28\%) and SingE (62\%) while simple past came next to be the verb used in protasis of PhilE (24) and SingE (25).

(21) ... if I leave $<$ ICE-HK:W2F-016>

(22) If Asia collapses... < ICE-PHI:W2B-011>

(23) ... if a university produces only one type of person. <ICE-SIN:W2E-002>

(24) If Chomsky (1964) criticized this view ... < ICE-PHI: W1A-020>

(25) ... if after so many years she still found in it an intrinsic fascination. <ICE-SIN:W2F$020>$

Meanwhile, modal + verb was also used to express the verb in the if-clause in SingE (26) and HKE (27).

(26) ... if all cars in Singapore can switch. <ICE-SIN:W2E-002> 
(27) ... if the Secretary for Civil Service could not be removed for failing to push through the Chief Executive's agenda. <ICE-HK:W2E-002>

Table 4. Comparison of verb forms in if-clause of three Corpora (Written)

\begin{tabular}{lcccccc}
\hline & \multicolumn{2}{c}{ PH } & \multicolumn{2}{c}{ HK } & \multicolumn{3}{c}{ SING } \\
\multicolumn{1}{c}{ Verb form } & F & $\%$ & F & $\%$ & F & $\%$ \\
\hline Simple Present & 353 & 68.28 & 352 & 69.43 & 633 & 62.00 \\
Simple Past & 92 & 17.79 & 57 & 11.24 & 164 & 16.06 \\
will + base & 13 & 2.51 & 3 & 0.59 & 6 & 0.59 \\
present perfect & 29 & 5.61 & 11 & 2.17 & 38 & 3.72 \\
Will + present perfect & 0 & 0.00 & 0 & 0.00 & 0 & 0.00 \\
Past perfect & 10 & 1.93 & 8 & 1.58 & 14 & 1.37 \\
must + present perfect & 0 & 0.00 & 1 & 0.20 & 0 & 0.00 \\
might + present perfect & 0 & 0.00 & 0 & 0.00 & 0 & 0.00 \\
would + present perfect & 1 & 0.19 & 1 & 0.20 & 0 & 0.00 \\
present progressive & 1 & 0.19 & 11 & 2.17 & 0 & 0.00 \\
past progressive & 0 & 0.00 & 1 & 0.20 & 3 & 0.29 \\
present perfect progressive & 4 & 0.77 & 0 & 0.00 & 0 & 0.00 \\
past perfect progressive & 3 & 0.58 & 0 & 0.00 & 0 & 0.00 \\
modal + base & 11 & 2.13 & 62 & 12.23 & 163 & 15.96 \\
Total & 517 & 100.00 & 507 & 100.00 & 1021 & 100.00 \\
\hline
\end{tabular}

On the other hand, in Table 5, simple present (28) and modal + verb (29) were the ones found most in the main clause of PhilE and SingE. Surprisingly, modal + verb (30), not simple present was the most frequent verb form in HKE. In addition, will + verb was also one of the top three mostly used forms in HKE and PhilE.

(28) If dinoflagellates are found... <ICE-PHI:W2B-030>

(29) If business by its own socially responsible actions can head off new government regulations... <ICE-SIN:W2A-017>

(30) ... if you can throw a ball into a ring attached to a 3.05m-high post. <ICE-HK:W2D$014>$ 
Table 5. Comparison of verb forms in the main clause of three Corpora (Written)

\begin{tabular}{lcccccc}
\hline & \multicolumn{2}{c}{ PH } & \multicolumn{2}{c}{ HK } & \multicolumn{2}{c}{ SING } \\
& Verb form & F & F & $\%$ & F & $\%$ \\
\hline Simple Present & 243 & 47.00 & 150 & 29.59 & 403 & 39.47 \\
Simple Past & 34 & 6.58 & 10 & 1.97 & 102 & 9.99 \\
will + base & 86 & 16.63 & 115 & 22.68 & 118 & 11.56 \\
present perfect & 21 & 4.06 & 4 & 0.79 & 8 & 0.78 \\
will + present perfect & 2 & 0.39 & 0 & 0.00 & 2 & 0.20 \\
Past perfect & 3 & 0.58 & 0 & 0.00 & 2 & 0.20 \\
could + present perfect & 0 & 0.00 & 1 & 0.20 & 0 & 0.00 \\
must + present perfect & 0 & 0.00 & 1 & 0.20 & 0 & 0.00 \\
might + present perfect & 0 & 0.00 & 1 & 0.20 & 0 & 0.00 \\
would + present perfect & 14 & 2.71 & 9 & 1.78 & 21 & 2.06 \\
present progressive & 1 & 0.19 & 3 & 0.59 & 1 & 0.10 \\
past progressive & 0 & 0.00 & 0 & 0.00 & 0 & 0.00 \\
present perfect progressive & 1 & 0.19 & 1 & 0.20 & 0 & 0.00 \\
past perfect progressive & 0 & 0.00 & 0 & 0.00 & 0 & 0.00 \\
modal + verb & 112 & 21.66 & 212 & 41.81 & 364 & 35.65 \\
Total & 517 & 100.00 & 507 & 100.00 & 1021 & 100.00 \\
\hline
\end{tabular}

Generally, the simple present form of the verb is the most frequently used in the if-clause and the main clause of both the spoken and written corpora of PhilE and SingE. However, protasis and apodosis of HKE used modal + verb in spoken and written corpus.

\subsection{Verb combinations in if-conditionals (Spoken)}

Based on the analysis of the three Asian English varieties, Table 6 reveals the verb combination found in conditional sentences of spoken PhilE. It is found that there are 762 occurrences of the simple present to simple present combinations (31) in the main clause and if-clause of the utterances.

(31) The group says the President deserves to be buried alive if he does not resign $<$ ICEPHI:S2B-004>

In addition, modal + verb and simple present correspondence (32) is also evident from the data while present perfect progressive with present perfect and present perfect progressive with present perfect progressive combinations are the least in the spoken PhilE. 
(32) if he is like a media mogul I might respect what he has to say <ICE-PHI:S1A-026>

Furthermore, modal + verb and simple present was the most frequent combination apparent in spoken HKE (33) while will + verb and simple present correspondence (34) gained 122 attestations from the said corpus. Meanwhile, very rarely did will + verb combined with simple present, will + verb, and modal + verb was used as a verb combination in the utterances.

(33) If a real American style committee system is adopted into the Legco then the Basic Law can surely be violated. <ICE-HK:S2A-034>

(34) After fifteen seconds if he or she carries on the speech there will be a series of bell ringing <ICE-HK:S2A-034>

Considering the SingE utterances, Table 8 shows that simple present in the if-clause and simple present in the matrix clause (35) were the most occurring usage in the data. Simple present verb form $(36,37)$ was also in combination with modal + verb (388) and will + verb (213).

(35) If my nodes are B1 A1 this whole lot on the right hand side is assumed to be known okay so in that case how to get hold of my unknowns <ICE-SIN:S1B-003>

(36) If only I know then we can start the show on Thursday night instead of $<$ ICESIN:S2B-035>

(37) If recent statements by our government are anything to go by the Alumni will play a greater role in the future development of our University <ICE-SIN:S2B-050>

Another interesting finding from the spoken corpus of SingE is the simple present and modal + verb combination (38) of conditional sentences while present progressive and simple progressive co-occurred only once in the spoken corpus. 
If-conditional sentences across Asian Englishes

Table 6. Verb combination of if-conditionals in PhilE (Spoken)

\begin{tabular}{|c|c|c|c|c|c|c|c|c|c|c|c|}
\hline Verb & $\begin{array}{l}\text { Simple } \\
\text { present }\end{array}$ & Simple past & $\begin{array}{l}\text { Will + } \\
\text { verb }\end{array}$ & Pres perfect & Past perfect & $\begin{array}{c}\text { Will + } \\
\text { present } \\
\text { perfect }\end{array}$ & $\begin{array}{c}\text { Would + } \\
\text { present } \\
\text { perfect }\end{array}$ & Present progressive & $\begin{array}{c}\text { Present perfect } \\
\text { progressive }\end{array}$ & $\begin{array}{l}\text { Past perfect } \\
\text { progressive }\end{array}$ & $\begin{array}{l}\text { Modal + } \\
\text { verb }\end{array}$ \\
\hline Simple present & 762 & 75 & 139 & 79 & 4 & 5 & 1 & 3 & 4 & 1 & 163 \\
\hline Simple past & 61 & 38 & 12 & 6 & 3 & 1 & 9 & 0 & 1 & 0 & 57 \\
\hline Will + verb & 44 & 6 & 21 & 6 & 0 & 1 & 0 & 0 & 1 & 0 & 5 \\
\hline Pres perfect & 75 & 3 & 11 & 10 & 3 & 0 & 0 & 0 & 0 & 0 & 11 \\
\hline Past perfect & 6 & 2 & 1 & 0 & 1 & 0 & 2 & 0 & 0 & 0 & 6 \\
\hline $\begin{array}{l}\text { Will }+ \text { present } \\
\text { perfect }\end{array}$ & 2 & 0 & 0 & 0 & 0 & 1 & 0 & 0 & 0 & 0 & 0 \\
\hline $\begin{array}{l}\text { Would }+ \text { present } \\
\text { perfect }\end{array}$ & 0 & 0 & 0 & 0 & 0 & 0 & 0 & 0 & 0 & 0 & 3 \\
\hline Present Progressive & 4 & 1 & 0 & 0 & 1 & 0 & 0 & 0 & 0 & 0 & 1 \\
\hline $\begin{array}{l}\text { Present perfect } \\
\text { progressive }\end{array}$ & 0 & 0 & 0 & 1 & 0 & 0 & 0 & 0 & 1 & 0 & 0 \\
\hline $\begin{array}{ll}\text { Past } & \text { perfect } \\
\text { progressive } & \end{array}$ & 1 & 0 & 0 & 0 & 0 & 0 & 1 & 0 & 0 & 0 & 1 \\
\hline Modal + verb & 47 & 12 & 3 & 3 & 1 & 1 & 0 & 0 & 0 & 0 & 18 \\
\hline
\end{tabular}


Ariel Robert C. Ponce \& Shirley N. Dita

Table 7. Verb combination of if-conditionals in HKE (Spoken)

\begin{tabular}{|c|c|c|c|c|c|c|c|c|c|c|c|}
\hline Verb & $\begin{array}{l}\text { Simple } \\
\text { Present }\end{array}$ & Simple Past & Will +verb & Present perfect & Past perfect & $\begin{array}{l}\text { Will + } \\
\text { present } \\
\text { perfect }\end{array}$ & $\begin{array}{l}\text { Would + } \\
\text { present } \\
\text { perfect }\end{array}$ & Present progressive & $\begin{array}{c}\text { Could }+ \\
\text { Present perfect }\end{array}$ & $\begin{array}{l}\text { Might }+ \\
\text { present } \\
\text { perfect }\end{array}$ & $\begin{array}{c}\text { Modal }+ \\
\text { verb }\end{array}$ \\
\hline Simple present & 96 & 0 & 122 & 1 & 0 & 1 & 2 & 3 & 2 & 2 & 140 \\
\hline Simple past & 3 & 3 & 12 & 0 & 1 & 0 & 3 & 0 & 1 & 0 & 30 \\
\hline Will + verb & 1 & 0 & 2 & 0 & 0 & 0 & 0 & 0 & 0 & 0 & 1 \\
\hline Present perfect & 2 & 0 & 2 & 1 & 0 & 0 & 1 & 0 & 1 & 1 & 5 \\
\hline Past perfect & 1 & 1 & 0 & 0 & 0 & 0 & 4 & 0 & 0 & 0 & 4 \\
\hline Present progressive & 4 & 0 & 4 & 0 & 0 & 0 & 0 & 1 & 0 & 0 & 8 \\
\hline Modal +verb & 9 & 3 & 12 & 0 & 0 & 0 & 0 & 3 & 0 & 0 & 24 \\
\hline
\end{tabular}


(38) if Singapore needs a historical model for Chinese culture it should be that of Tang China <ICE-SIN:S2B-019\#88:3:C>

Table 8. Verb combination of if-conditionals in SingE (Spoken)

\begin{tabular}{|c|c|c|c|c|c|c|c|c|c|}
\hline \multirow[b]{2}{*}{ Verb } & \multirow[b]{2}{*}{$\begin{array}{l}\text { Simple } \\
\text { present }\end{array}$} & \multirow[b]{2}{*}{$\begin{array}{c}\text { Simple } \\
\text { past }\end{array}$} & \multirow[b]{2}{*}{$\begin{array}{l}\text { Will } \\
+ \\
\text { verb }\end{array}$} & \multirow[b]{2}{*}{$\begin{array}{l}\text { Present } \\
\text { perfect }\end{array}$} & \multirow[b]{2}{*}{$\begin{array}{c}\text { Past } \\
\text { perfect }\end{array}$} & \multirow{2}{*}{$\begin{array}{c}\text { Would } \\
+ \\
\text { present } \\
\text { perfect }\end{array}$} & \multirow[b]{2}{*}{$\begin{array}{c}\text { Present } \\
\text { progressive }\end{array}$} & \multirow{2}{*}{$\begin{array}{c}\text { Should } \\
+ \\
\text { present } \\
\text { perfect }\end{array}$} & \multirow[b]{2}{*}{$\begin{array}{l}\text { Modal } \\
+ \text { verb }\end{array}$} \\
\hline & & & & & & & & & \\
\hline $\begin{array}{l}\text { Simple } \\
\text { present }\end{array}$ & 873 & 39 & 213 & 31 & 3 & 6 & 2 & 2 & 388 \\
\hline Simple past & 74 & 15 & 12 & 3 & 1 & 12 & 0 & 0 & 49 \\
\hline Will + verb & 4 & 2 & 0 & 0 & 0 & 3 & 0 & 0 & 4 \\
\hline $\begin{array}{l}\text { Present } \\
\text { perfect }\end{array}$ & 15 & 0 & 2 & 0 & 0 & 0 & 0 & 0 & 16 \\
\hline Past perfect & 3 & 2 & 0 & 0 & 0 & 3 & 0 & 0 & 4 \\
\hline $\begin{array}{l}\text { Will } \\
\text { present } \\
\text { perfect }\end{array}$ & 1 & 0 & 0 & 0 & 0 & 0 & 0 & 0 & 0 \\
\hline $\begin{array}{l}\text { Present } \\
\text { progressive }\end{array}$ & 1 & 0 & 0 & 0 & 0 & 0 & 0 & 0 & 0 \\
\hline $\begin{array}{l}\text { Past } \\
\text { progressive }\end{array}$ & 0 & 1 & 0 & 0 & 0 & 2 & 0 & 0 & 0 \\
\hline Modal $\quad+$ & & & & & & & & & \\
\hline verb & 152 & 11 & 42 & 4 & 1 & 1 & 0 & 79 & 0 \\
\hline
\end{tabular}

From the verb combinations used in the conditional sentences of the three Asian English varieties, simple present in the protasis and simple present and modal + verb in the apodosis of conditional sentences of PhilE and SingE were the most popular verb combinations. However, HKE has different verb combinations in its conditional sentences. Simple present verb form in the if-clause was frequently combined with modal + verb (39) and will + verb (40) in the matrix clause of the spoken HKE. 
(39)Now $<,>$ so there is a $<$. $>$ incre $</ .>$ if there is an increase on mass in the element $<,>$ the the volume of the element cannot change it must be delta $\mathrm{X}$ delta $\mathrm{Y}$ delta $\mathrm{E} Z$

(40) if other proposals command $<$, > more support $<,>$ than the proposals that we have put forward $<,>$ we will consider those $<\mathrm{O}>$ member's-question $</ \mathrm{O}><$ ICE-HK:S1B059\#33:1:A>

\subsection{Verb combinations in if-conditionals (Written)}

Different verb combinations were also observable in the written counterpart of the three corpora. It can be obtained from Table 9 the list of verb orders in the if-clause and main clause of written PhilE.

Among the 517 conditional sentences in the corpus, 185 of which were written with the simple present (39) in both clauses, and 72 sentences were found to have simple present and will + verb combinations (40) in the conditional clause and matrix clause, respectively. On the other hand, would + present perfect and simple past were the least used combination in the data.

(39) If he wants to resign, then obviously he is free to do so. <ICE-PHI:W2C-006>

(40) If it fails to reach an amicable agreement with the Marcoses in the sharing of the Marcos loot, all the pending cases will then be transferred to the custody of the Department. <ICE-PHI: W2C-007> 
Table 9. Verb combination of if-conditionals in PhilE (Written)

\begin{tabular}{|c|c|c|c|c|c|c|c|c|c|c|}
\hline Verb & $\begin{array}{l}\text { Simple } \\
\text { present }\end{array}$ & $\begin{array}{c}\text { Simple } \\
\text { past }\end{array}$ & $\begin{array}{l}\text { will + } \\
\text { verb }\end{array}$ & $\begin{array}{l}\text { Present } \\
\text { perfect }\end{array}$ & $\begin{array}{c}\text { past } \\
\text { perfect }\end{array}$ & $\begin{array}{l}\text { Will + } \\
\text { present } \\
\text { perfect }\end{array}$ & $\begin{array}{c}\text { Would } \\
+ \\
\text { present } \\
\text { perfect }\end{array}$ & $\begin{array}{c}\text { Present } \\
\text { progressive }\end{array}$ & $\begin{array}{c}\text { Present } \\
\text { perfect } \\
\text { progressive }\end{array}$ & $\begin{array}{l}\text { Modal } \\
+ \text { verb }\end{array}$ \\
\hline $\begin{array}{l}\text { Simple } \\
\text { present }\end{array}$ & 185 & 12 & 72 & 17 & 2 & 1 & 2 & 1 & 0 & 61 \\
\hline Simple past & 25 & 17 & 5 & 0 & 1 & 1 & 7 & 0 & 1 & 35 \\
\hline $\begin{array}{l}\text { Will }+ \text { base } \\
\text { form }\end{array}$ & 7 & 0 & 6 & 0 & 0 & 0 & 0 & 0 & 0 & 0 \\
\hline $\begin{array}{l}\text { Present } \\
\text { perfect }\end{array}$ & 17 & 1 & 3 & 4 & 0 & 0 & 2 & 0 & 0 & 2 \\
\hline $\begin{array}{l}\text { Would + } \\
\text { present } \\
\text { perfect }\end{array}$ & 0 & 1 & 0 & 0 & 0 & 0 & 0 & 0 & 0 & 0 \\
\hline $\begin{array}{l}\text { Present } \\
\text { perfect } \\
\text { progressive }\end{array}$ & 1 & 1 & 0 & 0 & 0 & 0 & 0 & 0 & 0 & 2 \\
\hline $\begin{array}{l}\text { past perfect } \\
\text { progressive }\end{array}$ & 1 & 1 & 0 & 0 & 0 & 0 & 0 & 0 & 0 & 1 \\
\hline
\end{tabular}

Similarly, HKE is found to have exhausted the use of simple present and modal + verb combinations (41) in their writing although simple present in the conditional clause and simple present in the main clause also cooccurred in the sentences.

(41) If I pass, I can have private tutorial of my violin by some professors.

Unpredictably, would + present perfect and simple past combination, along with must + present perfect and modal + verb orders, was the least occurring combinations in the written data. 
Table 10. Verb combination of if-conditionals in HKE (Written)

\begin{tabular}{|c|c|c|c|c|c|c|}
\hline Verb & $\begin{array}{l}\text { Simple } \\
\text { present }\end{array}$ & Simple past & $\begin{array}{l}\text { Present } \\
\text { perfect }\end{array}$ & $\begin{array}{l}\text { Would + } \\
\text { present } \\
\text { perfect }\end{array}$ & $\begin{array}{c}\text { Present } \\
\text { progressive }\end{array}$ & $\begin{array}{c}\text { Modal + } \\
\text { verb }\end{array}$ \\
\hline Simple present & 118 & 4 & 4 & 1 & 2 & 135 \\
\hline Simple past & 8 & 4 & 0 & 3 & 0 & 35 \\
\hline Will + verb & 1 & 0 & 0 & 0 & 0 & 0 \\
\hline Past perfect & 0 & 0 & 0 & 5 & 0 & 3 \\
\hline $\begin{array}{l}\text { Present } \\
\text { progressive }\end{array}$ & 4 & 0 & 0 & 0 & 0 & 4 \\
\hline $\begin{array}{l}\text { Past } \\
\text { progressive }\end{array}$ & 0 & 0 & 0 & 0 & 0 & 1 \\
\hline Modal + verb & 15 & 1 & 0 & 0 & 1 & 32 \\
\hline
\end{tabular}

Albeit lesser verb combinations were found in SingE compared with PhilE, simple present and simple present combination (42) and simple present and modal + verb sequence (43) saturated the written data.

(42) If B-hCG is negative ( less than $5 \mathrm{miu} / \mathrm{ml}$ ) at 8 weeks, the risk of residual trophoblastie disease is $1: 1000$ or lower'2. <ICE-SIN:W2A-030>

(43) if circumstances change, for instance, the husband earns more, and the wife finds the maintenance order is inadequate, either party may return to Court for a Variation Order. $<$ ICE-SIN:W2B-002>

Similarly, modal + verb and modal + verb order (44) were also evident in SingE writing. Meanwhile, past progressive paired with would + present perfect and modal + verb combinations were the least verb orders used in the variety.

(44) It would be appreciated if copies of this circular could be sent to staff members who are away on leave overseas. $<\mathrm{X}><\mathrm{ICE}-\mathrm{SIN}: \mathrm{W} 1 \mathrm{~B}-027>$ 
Table 11. Verb combination of if-conditionals in SingE (Written)

\begin{tabular}{|c|c|c|c|c|c|c|c|c|c|c|c|}
\hline Verb & $\begin{array}{l}\text { Simple } \\
\text { present }\end{array}$ & $\begin{array}{c}\text { Simple } \\
\text { past }\end{array}$ & $\begin{array}{c}\text { Will } \\
+ \\
\text { verb }\end{array}$ & $\begin{array}{l}\text { Present } \\
\text { perfect }\end{array}$ & $\begin{array}{c}\text { Past } \\
\text { perfect }\end{array}$ & $\begin{array}{c}\text { Would } \\
+ \\
\text { present } \\
\text { perfect }\end{array}$ & $\begin{array}{l}\text { Will + } \\
\text { present } \\
\text { perfect }\end{array}$ & $\begin{array}{c}\text { Present } \\
\text { progressive }\end{array}$ & $\begin{array}{c}\text { Should } \\
+ \\
\text { present } \\
\text { per }\end{array}$ & $\begin{array}{c}\text { Might } \\
+ \\
\text { present } \\
\text { par }\end{array}$ & $\begin{array}{l}\text { Modal } \\
+ \text { verb }\end{array}$ \\
\hline $\begin{array}{l}\text { Simple } \\
\text { present }\end{array}$ & 293 & 28 & 87 & 6 & 1 & 6 & 0 & 1 & 2 & 0 & 209 \\
\hline $\begin{array}{l}\text { Simple } \\
\text { past }\end{array}$ & 31 & 51 & 10 & 1 & 1 & 6 & 0 & 0 & 1 & 0 & 62 \\
\hline Will + verb & 3 & 1 & 1 & 0 & 0 & 0 & 0 & 0 & 0 & 0 & 1 \\
\hline $\begin{array}{l}\text { Present } \\
\text { perfect }\end{array}$ & 22 & 1 & 7 & 0 & 0 & 1 & 1 & 0 & 0 & 0 & 6 \\
\hline $\begin{array}{l}\text { Past } \\
\text { progressive }\end{array}$ & 0 & 0 & 0 & 0 & 0 & 1 & 0 & 0 & 0 & 0 & 2 \\
\hline $\begin{array}{l}\text { Modal }+ \\
\text { verb }\end{array}$ & 50 & 18 & 13 & 0 & 0 & 2 & 0 & 0 & 0 & 0 & 80 \\
\hline
\end{tabular}

With the data from the written aspect of the three English varieties, it is clear that the simple present and simple present verb combination was most frequent in both PhilE and SingE although HKE also employed such a combination, but not as much as the other two varieties as HKE mostly used the simple present and modal + verb blend in its written corpus.

Surprisingly, would + present perfect and simple past pattern was almost totally absent across the three written corpora, which may be due to the complexity of these verb combinations and that most simplified reference materials would prescribe a simple past + would + base form of the verb instead of a would + perfective.

(45) Now if any of this fluid or water got inside your mouth it would have spit it out right $<\mathrm{O}>\quad$ 'right ' overlaps 'jia ru ' $\mid \mathrm{xA} 8 \mathrm{C}$ ' if ' $</ \mathrm{O}><\mathrm{O}>$ Putonghua translation and answer $<$ ICE- HK:S1B-067\#218:1:A> (46) if I meant a lion or a tiger I would have said so. <ICE-SIN:W2F-008\#68:1> 


\subsection{Semantic categories of the conditional sentence in spoken corpora}

After structurally analyzing the verb forms and combinations across the three Asian varieties of English, the data was subject to a cross-tabulation of the conditional sentences against its semantic categories in spoken PhilE, HKE, and SingE.

As can be seen in Table 12, it reveals that PhilE (92.19\%) has the most number of open conditional utterances (45) while open conditionals were the least in spoken $\operatorname{HKE}(73.11 \%)$. Conversely, HKE had the most number of hypothetical conditional declarations (46) with 26.89\% of its corpus. Meanwhile, PhilE with only $7.81 \%$ had very rare instances of hypothetical spoken expressions (47).

(45) And I think it will be uh it would make a great impact on his finances if he stops in that show <ICE-PHI:S1A-025>

(46) Could we have won if we have done more? <ICE-HK:S2B-030>

(47) if $<@>$ Canlas $</ @>$ has first-hand information on the transaction as it were $<$ indig $>$ 'no </indig $>$ then she would make for a good witness < <CE-PHI:S1B-034>

Table 12. Comparison of the semantic category of spoken if-conditionals

\begin{tabular}{ccccccc}
\hline & \multicolumn{2}{c}{ PhilE } & \multicolumn{2}{c}{ HKE } & \multicolumn{2}{c}{ SingE } \\
Semantic category & F & $\%$ & F & $\%$ & F & $\%$ \\
\hline open & 1605 & 92.19 & 378 & 73.11 & 1590 & 76.7 \\
hypothetical & 136 & 7.81 & 139 & 26.89 & 482 & 23.3 \\
Total & 1741 & 100 & 517 & 100 & 2072 & 100 \\
\hline
\end{tabular}

Upon cross-tabulation, open conditionals in spoken PhilE would have simple present in the if-clause combined with the simple present (48) and modal + verb (49) in the matrix clause. In addition, simple present co-occurred with modal+ verb in hypothetical conditionals of PhilE spoken corpus.

(48) if a pregnant mother decides she does not want to have a baby because it's going to be painful isn't that rather stupid <ICE-PHI:S1B-025>

(49) If ever you decide to take up this major okay I would suggest uhm if you want to raise the level of your computer uh literacy you can also take up some courses that... $<$ ICE-PHI:S2A-049> 
Regarding the spoken corpus of ICE-Hong Kong, simple present existed with will + verb (50) and modal + verb (51) in open conditionals while simple present verb form in protasis and modal + verb in apodosis were paired in most hypothetical conditional sentences in spoken HKE.

(50) So that $<.>$ i $</$. $>$ if we further delay the overall cost of the airport core project will go up definitely. $<$ ICE-HK:S2B-002>

(51) If we have an independent body outside the police uh you would need of course uh manpower additional resources... <ICE-HK:S2B-012>

Spoken Singaporean English, moreover, was filled with simple present and modal + verb patterns (52) in both open and hypothetical conditional sentences.

(52) If deterrence and diplomacy fail, the Singapore Armed Forces ( SAF) are expected to secure a swift and decisive victory over the aggressor. <ICE-SIN:W1A-009>

Overall, the spoken corpora used simple present and modal + verb patterns in the open conditionals of HKE and SingE while PhillE in its open conditionals mainly followed simple present forms in both main clause and if-clause. Moreover, simple present and modal + verb were the verb combinations found in the hypothetical conditional utterances across the three Asian varieties of English.

\subsection{Semantic categories of the conditional sentence in written corpora}

Like the spoken aspect of the corpora, findings of the written corpus of PhilE, HKE and SingE were also computed for a cross-tabulation of if-conditional sentences and the semantic categories.

As shown in Table 13, PhilE, which yielded 92.8\%, obtained the most number of open conditional sentences (53) across the three Asian varieties and HKE gained the least number of open conditionals which comprised $77.91 \%$ of its total written corpus. Moreover, as can be seen in the same table, hypothetical conditionals were the least in PhilE while HKE gained the highest number of hypotheticals (54) in the data.

(53) House leaders said it would be difficult for the ethics committee probe on $<$ @ $>$ Jimenez $</ @>$ to prosper If it has intrinsic merit, its value appreciates... $<$ ICE-PHI:W2B$001>$

(54) If there is an NPO in our area, policemen stationed there who are familiar with the district would find it easier to get around, \&rdquo; she said. $\quad<$ ICE-HK:W2C-020> 
Table 13. Comparison of the semantic category of written if-conditionals

\begin{tabular}{lcccccc}
\hline & \multicolumn{2}{c}{ PhilE } & \multicolumn{2}{c}{ HKE } & \multicolumn{2}{c}{ SingE } \\
Semantic category & F & $\%$ & F & $\%$ & F & $\%$ \\
\hline open & 480 & 92.8 & 395 & 77.91 & 825 & 80.8 \\
hypothetical & 37 & 7.2 & 112 & 22.09 & 196 & 19.2 \\
Total & 517 & 100 & 507 & 100.00 & 1021 & 100 \\
\hline
\end{tabular}

With respect to verb combinations of semantic categories of conditional sentences in written corpora across three varieties, the data revealed that open conditionals (55) in PhilE followed a simple present verb form in both the if-clause and matrix clause. Moreover, simple past and modal + verb orders (56) were found among hypothetical conditional sentences in the corpus.

(55) If life is threatened, there is no option but to close seafarming sites permanently. $<$ ICE-PHI:W2B-030>

(56) if the father tried to \&ldquo; re-write \&rdquo; Oedipus ' life, he still couldn't and neither could Oedipus because of destiny. <ICE-PHI:W1A-014>

In written $\mathrm{HKE}$, the simple present verb in protasis seemed to combine with simple present and modal + verb in the apodosis (57) in open conditionals while two popular combinations were noticed in the hypothetical conditional sentences. These were simple past with modal + verb and modal + verb with modal + verb, having a majority of modal + verb in the matrix clause of written HKE hypothetical conditionals.

(57) If no heater is fitted during construction, the standard aperture can be sealed by easilyremovable brickwork or blockwork. <ICE-HK:W2A-035>

(58) If I $<$ ul $>$ knew $</$ ul $>$ it , I would have done it \&rsquo; <ICE-HK:W1A-011\#126:1> (59) We should appreciate it if you would provide us with the outcome of your investigation. <ICE-HK:W1B-023>

Interestingly, the simple present verb in both protasis and apodosis was the combination in most open conditionals (60) in SingE. Meanwhile, simple present and modal + verb were the verb sequence in the hypothetical conditional sentences.

(60) If he is asked to justify and quantify his hunch, he gets upset. <ICE-SIN:W2C-001>

Thus, the written corpora of three varieties of English were observed to have exhausted the use of simple present verb orders in the if-clause and matrix clause of open conditional sentences, which are neutral expressions because they do not absolutely demonstrate whether the conditions 
will be accomplished or not, in PhilE and SingE, while HKE mainly used simple present and modal + verb combination.

On the other hand, hypothetical conditionals, which express the impossibility of the truth value of the proposition expressed by the matrix clause, of in SingE and HKE generally had simple present and modal + verb order of the verb in protasis and apodosis, respectively.

\section{Results and Discussion}

Using the International Corpus of English (ICE), this paper explores the if-conditional sentences of three Asian English varieties, namely PhilE, HKE, and SingE. The findings of the study revealed that simple present is a widely used verb form in the if-clause across the three varieties of spoken English.

(61) The group says the President deserves to be buried alive if he does not resign $<$ ICEPHI:S2B-004>

(62) If a real American style committee system is adopted into the Legco then the Basic Law can surely be violated. <ICE-HK:S2A-034>

(63) If my nodes are B1 A1 this whole lot on the right hand side is assumed to be known okay so in that case how to get hold of my unknowns $<$ ICE-SIN:S1B-003 $>$

Similarly, the main clause of the if-conditional sentences in the three corpora maximized the use of simple present particularly in PhilE and SingE, but not with HKE. Additionally, when the written corpora were surveyed, a similar finding with the spoken corpora was found, that is, the simple present was evident in both the main clause and conditional clause of PhilE and SingE. This suggests that these verb phrase combinations have been widely used in these corpora regardless of the semantic categories of the sentences. We argue that the simplicity of these verb structures makes them easy to be remembered and used in utterances by the majority of the Filipinos and Singaporeans.

Upon doing the cross-tabulation of the verb combinations and if-conditionals from the spoken and written corpora, the most frequent verb order found was the simple present in the conditional clause and simple present in the matrix clause for both PhilE and SingE. This particular finding concurs with that of Wang's (1991). She found that the simple present was the most common verb combinations in conditional sentences in Brown Corpus and LOB Corpus with both $22 \%$. We conjecture that this is the case because, among users of English, this is the least 
complicated verb form to memorize and use. In particular, Borlongan (2010) mentioned that Filipinos tend to use simpler verb phrases and avert the more complex ones. However, what is striking in the result is the different verb sequences in the HKE. Very consistently, HKE had employed simple present and modal + verb in both clauses of spoken and written corpus which is consistent with two arguments of scholars. On the one hand, Carter and McCarthy (2006) noted that "modals other than will/would are used, as well as different future-referring expressions, including the simple present" (in Hasselgård, 2016, p. 99), and on the other hand, Gabrielatos (2010) argued that conditional sentence types and modality correlated with respect to the if-clause and the main clause.

Another interesting finding of this study is the seeming absence of the would + present perfect and simple past constructions (see 64) in all the corpora even in the written aspect. This is indicative of non-use of language users of this particular typology despite the convention proposed in the grammar books.

(64) If it didn't $<$ unclear $>$ word $<$ /unclear $>$ in English, you would have got the immigration job $<$ \$C $><$ ICE-SIN:S1A-088\#266:1:C $>$

As regards the semantic categories in both the spoken and written corpora, generally, PhilE had the most number of open conditional sentences and the least number of hypothetical conditionals. This means that users of PhilE variety had more constructions that are either factual or predictive in nature. We speculate that this is the case because verb phrases used to express open conditional sentences such as present verb in both the main and conditional clauses (e.g. if a pregnant mother decides she does not want to have a baby because it's going to be painful, isn't that rather stupid) are easier and simpler to remember. Also, we think that hypothetical situations may not be usually expressed in English conditionals, but rather in the local language, because of the complexity of the verb combinations in English used to express hypothetical expressions. This result is consistent with Wang (1991 as cited in Kennedy, 1998) who found that Brown Corpus, an American English corpus, had two-thirds of its conditional sentences expressing open conditions. In a similar vein, Hasselgård (2016) also found that a little more than 50\% of the if-conditional sentences from BAWE and VESPA were classified as open conditional sentences. Meanwhile, HKE had the most number of hypothetical conditionals among the three varieties; however, it had the least occurrences of open conditionals. The results indicate a directly proportional relationship with that of the PhilE. While the results of Hasselgård (2016) favors the former finding, it simultaneously 
runs against the present result. She found that hypothetical conditions were only one-fifth of the corpora she investigated. This inconsistency in both the present and earlier findings suggests that even if HKE is heavily influenced by British English, it still may not have the same outlook on using semantically probable conditional sentences. However, it should be noted that the corpora are composed of different utterances from different domains and topics. Thus, the use of conditional sentences may vary depending on the topic of conversations or essays.

\section{Conclusion}

Conditional sentences are a complex grammatical category that is not easily mastered by most learners because of their very complex structure as discussed above. We found an estimate of 121 , at most, verb combinations across ICE-PHI, ICE-HK, and ICE-SING. This is almost twice more than what Wang (1991) found in Brown and LOB corpora and only one-third of what Hill (1960 in Kennedy, 1998) discovered.

The general findings of this study validate the notion forwarded by Celce-Murcia and Lancer-Freeman (1999). They argued that most ESL/EFL grammar references or textbooks offer extremely overgeneralized and very simplistic information about conditional constructions. With this, Gabrielatos $(2003,2006)$ strongly argued that "the pedagogical information in the coursebooks, taken collectively, presented learners not only with a partial picture of the variety of types of conditionals and their respective morphosemantic features, but also a distorted one" (cited in Gabrielatos, 2013, p.2). These arguments and findings suggest that the teaching of conditional sentences in schools should shift from being prescriptive to descriptive. As already proven, grammar books and course books used in ESL and EFL classrooms do not capture all the possible verb structure of conditional sentences.

Moreover, focusing only on if-conditional sentences and direct conditionals is one of the limitations of this paper. Therefore, an investigation of unless as a subordinator of conditional sentences is worth exploring. In addition, if-insubordination has been found to be more scarce in corpus-based studies (e.g. Lastres-López, 2018). With this, research on if-insubordination can be considered for a future investigation. Lastly, research on the conditional sentences in other ICE corpora can be explored to expand the arguments of the present study. 


\section{References}

Al Rdaat, S.H. (2017). An analysis of the use of conditional sentences by Arab students of English. Advances in Language and Literary Studies, 8(2), 1-13.

Bloom, L. Lahey, M. Hood, L. Lifer, K. and Fiess, K. (1980). Complex sentences: Acquisition of syntactic connectives and the meaning relations they encode. Journal of Child Language, 7, 235-261.

Celce-Murcia, M., \& Larsen-Freeman, D. (1999). The grammar book: An ESL/EFL teacher's course. New York: Heinle, Cengage learning.

Cooperstein, S. E., \& Kocevar-Weidinger, E. (2004). Beyond active learning: a constructivist approach to learning. Reference services review. Elder, C. \& Jaszczolt, K. (2016). Towards a pragmatic category of conditionals. Journal of Pragmatics, 98, 36-53.

Gabrielatos, C. (2003, September). Conditional Sentences: ELT typology and corpus evidence. In BAAL 36th Annual Meeting.

Gabrielatos, C. (2006, July). Corpus-based evaluation of pedagogical materials: If-conditionals in ELT coursebooks and the BNC. In 7th Teaching and Language Corpora Conference.

Gabrielatos, C. (2010). A corpus-based examination of English if-conditionals through the lens of modality: Nature and types. Doctoral dissertation, Lancaster University. http://ethos.bl.uk/OrderDetails.do?did=1\&uin=uk.bl.ethos.539699

Gabrielatos, C. (2013). If-conditionals in ICLE and the BNC: A success story for teaching or learning? Twenty Years of Learner Corpus Research: Looking back, In S. Granger, G. Gilquin \& F. Meunier (eds.) Twenty Years of Learner Corpus Research: Looking back, moving ahead (pp. 155-166). Louvain-la-Neuve, Belgium: Presses Universitaires de Louvain.

Gauker, C. (2005). Conditionals in context.

Hill, L. A. (1960). The sequence of tenses with “if”-clauses. Language Learning, 10(3-4), 165178.

Hasselgård, H. (2016). Conditional clauses in novice academic English: A comparison of Norwegian learners and native speakers. Nordic Journal of English Studies 15(2), 95-112.

Kennedy, G. D. (1998). An introduction to corpus linguistics. London: Longman. 
Lastres-López, C. (2018). If-insubordination in spoken British English: Syntactic and pragmatic properties. Language Sciences, 66, 42-59.

Leech, G. (2011). Frequency, corpora, and language learning. In F. Meunier, S. De Cock, G. Gilquin \& M. Paquot (eds) A Taste for Corpora: In Honour of Sylviane Granger. Amsterdam \& Philadelphia: John Benjamins, 7-31.

Mejras-Bikandi, E. (2009). Conditional sentences and mood in Spanish. Journal of Pragmatics, $41,163-172$.

Quirk, R., Greenbaum, S., Leech, G., \& Svartvik, J. (1985). A Comprehensive Grammar of the English Language. London: Longman.

Wang, S. (1991). A corpus study of English conditionals. Unpublished MA thesis. Victoria University of Wellington. 